\title{
Formation of the modern business environment in the agricultural sector of the economy of Ukraine
}

\author{
Termosa I. \\ Hlukhiv National Pedagogical University named after Alexander Dovzhenko \\ 24 Kyievo-Moskovska Str., Hlukhiv, Sumy oblast, Ukraine \\ e-mail: bojarinova.ira13@gmail.com \\ ORCID: 0000-0002-4996-173X
}

\begin{abstract}
Goal. To reveal the influence of innovations and investments on the formation of the modern business environment, to characterize the types of innovations in the agricultural sector, and to propose an algorithm for their implementation. Methods. Dialectical methods of cognition of processes and phenomena, monographic method (analysis of the evolution of scientific achievements of Ukrainian and foreign scientists on the introduction of innovations and formation of the innovative business environment in the agrarian sector of the economy), comparative analysis (the basic differences of innovations in agro-industrial production), empirical (complex analysis of the object of study), abstract (theoretical generalizations and conclusions). Results. Theoretical and practical provisions for the formation of the modern business environment have been further developed, and the impact of innovations and investments on this process has been studied. The necessity of innovative activity of economic entities in the agricultural sector of the economy is substantiated. It is proved that investments are the basis for the formation of the modern business environment with innovative processes. In the historical context, the mechanism of introduction of the innovative approach to agricultural commodity production offered by prince V. Kudashev is studied. A specific example shows the positive impact of the innovative approach to agricultural production. They proposed an algorithm for introducing innovations in the production activities of economic entities in the agricultural sector. Conclusions. The main differences in innovations in the agricultural sphere are investigated. The essence of investments and their influence on the formation of the business environment is revealed.
\end{abstract}

Key words: innovations, innovation process, investments, agricultural commodity production, innovation-investment approach.

DOI: https://doi.org/10.31073/agrovisnyk202009-08

The agrarian sector of the economy has been and remains an important element of the socio-economic foundation of our state, which ensures food security of the state, generates new jobs, forms a stable export potential of the country and ensures the flow of foreign currency into the national economy. Thanks to the development of the agrarian sector of the economy, the development of the rural territories of Ukraine is taking place. The development of small and medium businesses in rural areas, in its turn, provides an opportunity for local communities to develop, improve the socio-economic standard of living of the rural population. The modern agrarian economy is an extremely complex system, the effective functioning of which is influenced by an amount of factors, and on which the national security of our state also depends.

The best indicators of the effective functioning of any economic system are the possibility of ensuring its constant growth and expansion, that is, ensuring its development. The indicators of the effectiveness of the development of the agrarian economy are an increase in the number of small and medium enterprises, an expansion of sales markets for their own products and an increase in their competitiveness, an increase in the social standards of living of the rural population.

The development of modern agrarian entrepreneurship takes place in a fairly saturated competitive environment, which is formed under the influence of scientific and technological progress, the development of the new technologies and innovations, the use of new approaches in crop and livestock production, and quite significant financial investments. Without financial support and the introduction of innovative technologies, it is impossible to provide competitive advantages both in the domestic market and in the foreign markets for the sale of our own agricultural products. Investments in innovation and innovation activity are the driving forces that form and ensure the development of the entrepreneurial environment in the agrarian sector of the economy, and therefore the study of their impact is extremely important and topical trends in scientific activity.

Analysis of recent research and publications. The works of both domestic and foreign authors are devoted to the study of the influence of innovation and investment on the formation of the modern business environment. Such domestic scientists as L. L. Antoniuk, A. M. Poruchnik, V. S. Savchuk [1], O. G. Melnik [2], P. T. Sabluk, O. G. Shpikuliak, L. I. Kurilo [3], N. G. Sirenko [4], V. F. Fedorenko, D. S. Buklagin, E. L. Aronov [5], L. I. Fedulova [6] and others.

The scientific works by such domestic scientists as S. S. Ivanochko, O. M. Svintsov [7], M. M. Leus [8], K. V. Pavlov [9], A. A. Peresada [10], M. I. Malik, M. F. Kropivko, O. G. Bulavka [11], O. M. Shevchuk, N. Yu. Rogozzhin [12] and others were devoted to the research of the impact of investments on the formation and development of the modern entrepreneurial environment. Also in this trend of scientific research such foreign scientists as J. Shumpeter (1992) [13], E. Denison (1985) [14], A. Jaffe, J. Lerner, S. Stern (2005) [15], M. Giarratana (2005) [16]. 
However, within the considerable number of scientific works about the problems of the formation of the modern business environment in the agrarian sector of the economy, there is a need for the further research, especially under conditions when our state is trying to implement the main theses of the concept of sustainable development in both the economic and the social segments of life.

The purpose of the article - is to reveal the essence of the influence of innovations and investments on the formation of the modern business environment, to characterize their types, to study the main characteristics of innovations in the agrarian sector and to propose an algorithm for their implementation.

Presentation of the main results of the research. Innovation fundamentally affects the degree of economic growth through the introduction of the results of intellectual work, such as new scientific and technical developments, new technology systems, etc. into the production process for their use in the own production process and on their principles to achieve more effective socio-economic effect in comparison with the previous production.

The term "innovation" first appeared in the studies of culturologists in the nineteenth century and meant the introduction of new elements of one culture into another [1], and the categories "innovation", "innovation process", "new combinations" were introduced into scientific circulation by J. Schumpeter, who referred making a new good, introducing a new production method, developing a new sales market, obtaining a new source of raw materials or semi-finished products, the implementation of the appropriate reorganization to the innovations [13].

Usually, innovation is primarily associated with improving the manufacturing process.

Investigating the impact of technological progress, R. Solow, D. Sakhal, R. Foster, B. Twiss, E. Denison [14, $17-$ 19] paid considerable attention to innovation, the innovation process and attempts to quantify the influence of innovation at the growth of national income.

It is also necessary to emphasize that modern innovative theories that are used today differ in categorical characteristics of innovations, argumentation in substantiating the transformational impact of innovations on economic dynamics, interpretation of the static and dynamic characteristics of the innovativeness of changes, concretization of research in the trend of scientific and technological progress: technical technological improvements and economic efficiency of system organizations, which are based on the productivity of innovations [2]. At this stage, a significant backlog in the development of innovative theory was made by such economists as A. Yaffe, J. Lerner, S. Stern, M. Gyaratana, S. Torrisi and A. Pagano [15-16], who investigated innovation issues from the standpoint of the theory of economic welfare and focused on the rapid economic growth of national economies that develop through innovation, and also made an attempt to highlight the factors of innovative growth. One of the most important factors of innovative development, according to scientists, is education.

Depending on the object and subject of research, innovations can be interpreted as changes (J. Schumpeter, Y. Yakovets, R. Nelson, S. Winter and others), as a process (D. Bessant, D. Tidd, K. Pavitt, B. Santo, B. Twiss, D. Chervanov, L. Neikova and others), as a result (R. Fatkhutdinov, H. Riggs, V. Hipel).

Innovation, as a driving force for development, has at least two directions. First, the diffusion of innovations and new technologies ensures modernization. Innovation improves productivity and ensures business vitality. Secondly, innovation is a prerequisite for the emergence of a new product, so innovation is a necessary condition for development [6].

Innovations in agro-industrial production are the implementation in economic practice of the results of scientific research, which are embodied in the fields of crop production and animal husbandry through new varieties of plants, breeds and species of animals, poultry crosses, new or improved food products, materials, new technologies in animal and crop production and processing industry, new methods of prevention and treatment of animals and poultry, new fertilizers and means of protection, new forms of organization and management of production, new approaches to the provision of social services that improve the efficiency of agricultural production.

In the broadest sense, agro-industrial innovations are defined as innovations that are implemented in the agrarian sector and provide the corresponding economic, environmental, social effect [3, 4, 20]. Agro-industrial innovations affect directly (or indirectly within the technological cycle) processes in which workers, machines (tools, equipment, etc.) and a component of the environment (animal, plant) are involved, the existence of which in the natural environment (without the participation of an employee ) is impossible or possible only with partial or complete loss of basic functional characteristics. A distinctive feature of agro-industrial innovations is the mandatory presence of a component that, being part of the environment, cannot exist without the participation of an employee.

Quite often, in the field of agro-industrial production, the term "innovation" is used to refer to processes related to the introduction of new technology, technological improvement of production processes, breeding and breeding work, with the achievement of new properties and combinations of properties of products that are sold on the market.

The complex nature of agro-industrial innovations, their complex nature, the variety of spheres and forms of use lead to the identification of clear criteria for classifications of innovations in agro-industrial production, which will allow a more specific, complete and objective assessment of innovations, determine their effectiveness and direction of innovative development, as well as determine management methods for each of the classification groups. There are different signs for the isolation of classification groups of agro-industrial innovations, which are proposed in the studies of P. T. Sabluk, O. G. Shpikuliak, L. I. Kurilo, V. F. Fedorenka [3, 5]. Given the specifics of the sphere, we highlight the most important classification features of agro-industrial innovations:

1. Degree of radicality (epochal, basic, improving, pseudoinnovation). Thus, the opportunity to use agriculture and cattle breeding became landmark innovations in the agrarian sphere. Basic are new types of production (genetically modified organisms, biotechnology, biofuels). Improved innovations contribute to the improvement or diffusion of basic innovations (improved crop varieties, new soil systems).

Pseudoinnovations cause external changes in products and technologies and do not change their consumer qualities (changing the way of advertising, design, etc.). 
2. Scope and subject matter: selection and genetic innovations; production and technological; organizational and management; social innovation; environmental innovations.

3. Target focus: innovations aimed at improving facilities that interact in the production process; innovations aimed at improving interaction within the agricultural production system; innovations aimed at improving interaction with the external environment of the agricultural business.

A feature of innovative processes in the agrarian sphere is that they involve a large number of participants who, to varying degrees, take part in different stages of the innovative process and affect the final efficiency and effectiveness. In this process, educational and scientific organizations of an agricultural profile, agricultural production management bodies, serving enterprises, agricultural enterprises take part. The main participants are scientific organizations, management bodies at different levels and directly agricultural producers of various organizational and legal forms. The former create innovations, including through the synthesis, development and adaptation of advanced foreign and domestic experience, and are interested in the practical application of developed technologies. Management bodies operate at the national and territorial levels and provide (organizationally, financially) processes for the dissemination and introduction of innovations. Manufacturers are interested in obtaining information on best practices and innovative technologies. The efficiency and effectiveness of innovation as a whole depends to a large extent on the coherence and effectiveness of interaction between different participants in the innovation process.

The scheme of the influence of innovations on the formation of an entrepreneurial environment in the agricultural sector is shown in Figure 1.

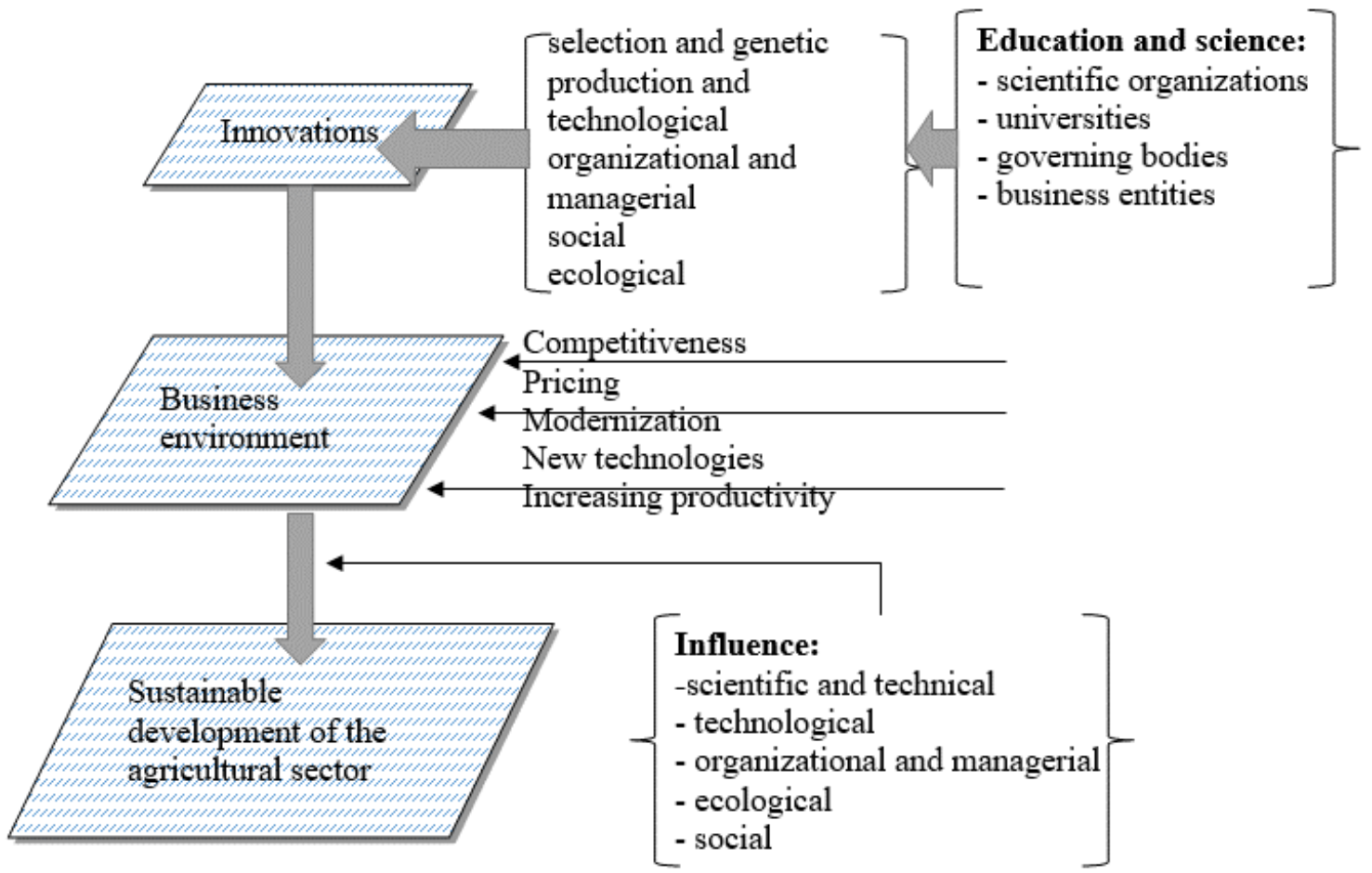

Figure 1. Research on the impact of innovation on the formation of an entrepreneurial environment Source: Generated from research.

Exploring the formation of an entrepreneurial environment in the agricultural sector under the influence of innovation, it should be noted that such an environment will be quite competitive, based on the introduction of new technologies, increasing productivity, and have rather flexible pricing. That is, such an entrepreneurial environment requires its participants - entrepreneurs, small, medium and large producers to be quite dynamic in the field of their own production, quickly responding to market requirements, modernize their own production, introduce new technologies and approaches to ensuring production processes, and constantly invest in their own development.

Innovations are primarily displayed in the material and technical base of economic entities. Even a superficial analysis of world experience demonstrates the formation and functioning of the agricultural economy on innovation. In this context, there is a rather constructive position of Malik M.I., who argues that competitive products cannot be developed by manual work and outdated equipment [11]. Therefore, the assessment of technical and technological factors in the formation and implementation of state investment policy in the agricultural sector is of great importance.

As a result of research, we can confidently assert that without an innovative component, the development of the agricultural sector of the economy will be impossible. But, such a statement also suggests that for the introduction of advanced achievements in science, technology and technology, the presence of another component is necessary investment.

Comprehensive and illustrative is the definition of the economic essence of investments, proposed by Blank I.O. "Investment is the investment of capital in all its forms in various objects (instruments) of economic activity for profit, as well as the achievement of another economic or non-economic effect, the implementation of which is based on market principles and associated with time, risk and liquidity factors" [21]. 
Shevchuk O. M. claims that... "From a financial point of view, investments are assets, funds that are invested in economic activities for the purpose of generating income, and from an economic one are expenses for the creation, expansion, reconstruction and technical re-equipment of fixed and working capital "[12].

As A. A. Peresada notes, investments in intangible assets are divided into innovative and intellectual. "... Innovative investments are investments in innovations." Most of the innovative form is made up of intellectual investments. "... Intellectual investments are investments in intellectual property objects that arise from copyright, inventive law, rights to industrial designs and utility models" [10, p. 134]. Ivanochko S. S. and Svintsov O. M., sharing the point of view of A. A. Peresada, believe that two more sub-points should be added to the proposed division: social and environmental. Where social will be aimed at solving social issues, and environmental - for the long-term perspective of solving environmental problems [7].

We are deeply convinced that the practical formation of an entrepreneurial environment is impossible without investment support, since investment is a key factor in the implementation of innovations. The influence of investments on the formation of an entrepreneurial environment is shown in Figure 2.

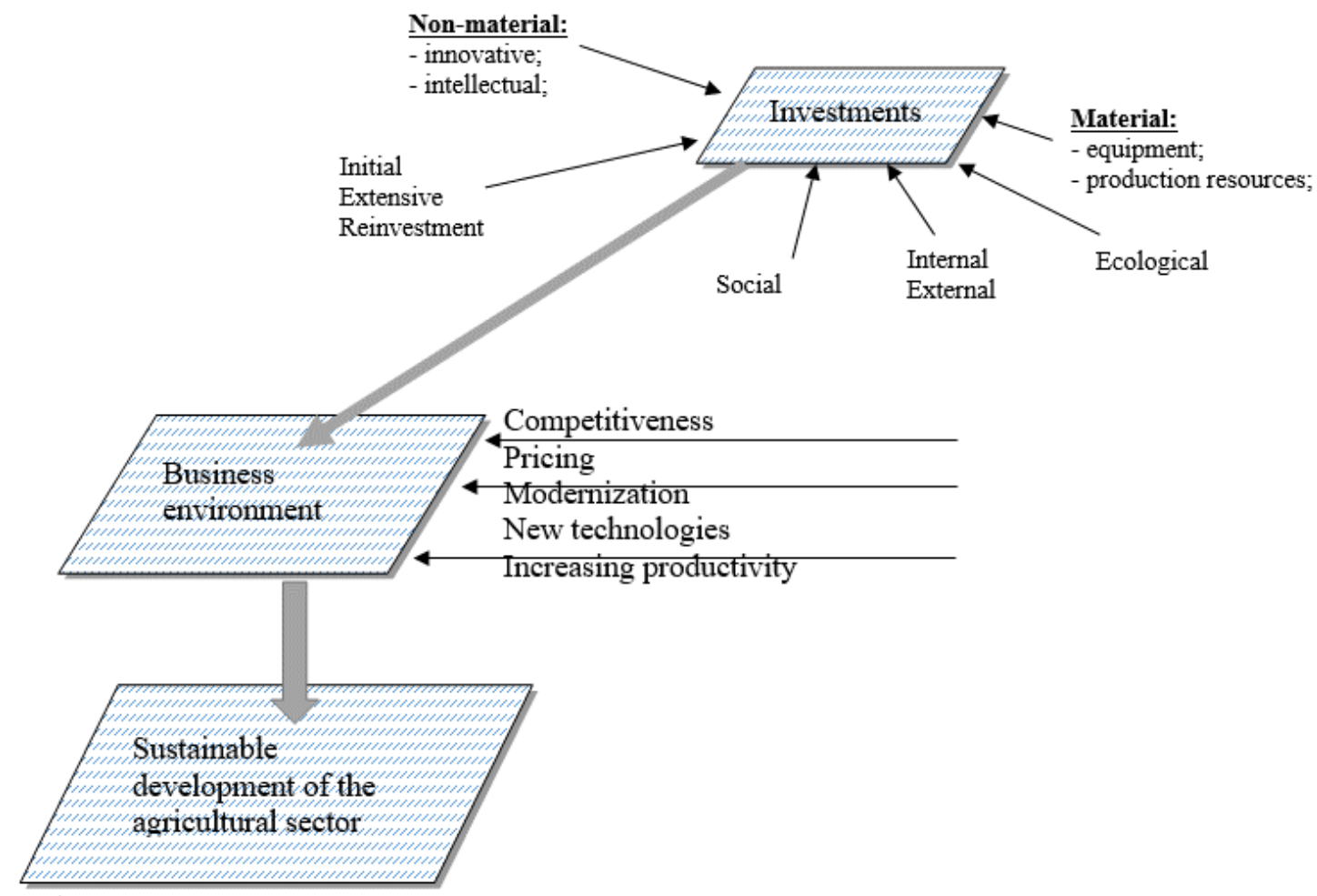

Fig. 2. Influence of investments on the formation of the business environment

Source: Formed on the basis of research [2, 4, 10, 20].

Different States have different forms of ownership. This important point is taken into account by researchers who have identified among the investments their types: public, private, foreign, collective and general. However, different authors focus only on certain species, which, in their opinion, have more characteristic features.

So, Fyodorenko V. G., Schukin B. M. distinguish state, private, foreign, general, Blank I. A. - only two types - state and private, Stadnichesky Yu. I. - three types - state, private and general, Peresada A. - three types - state, private and collective [10].

According to the criterion of directional action, according to Leus M. M., it is possible to distinguish: initial investments are necessary for the development of newly formed enterprises, or when introducing individual projects; extensive investment - which is used to expand production without substantial modernization; reinvestment - the profit obtained is not withdrawn from circulation of the enterprise, but is used to purchase securities, or attractions to working capital [8].

We consider the idea of Pavlov K. V., who classifies investments depending on their focus - on an extensive or intensive type of reproduction [9]. After all, not only the expansion of production, but also modernization, and the introduction of new technologies that should positively affect the investment climate in the entrepreneurial environment will depend on this direction.

So, in our deep conviction, the practical formation of the entrepreneurial environment will not be possible without investment support, since investment is a key factor in the introduction of innovation.

It should be emphasized that the innovative and investment approach to the formation of a modern entrepreneurial environment was begun in a rather long historical past. A vivid example of a scientific approach to agro-industrial production was the example of prince V.O. Kudashev.

So, in 1878, prince V.O. Kudashev at his own expense created a classical research industry institution - the Kiriyakovsky research field. This was the first such institution not only on modern Ukrainian lands, but also in the Russian Empire. The general scheme of the scientific and practical approach to agro-industrial production proposed by prince V.O. Kudashev is depicted in Figure 3. 


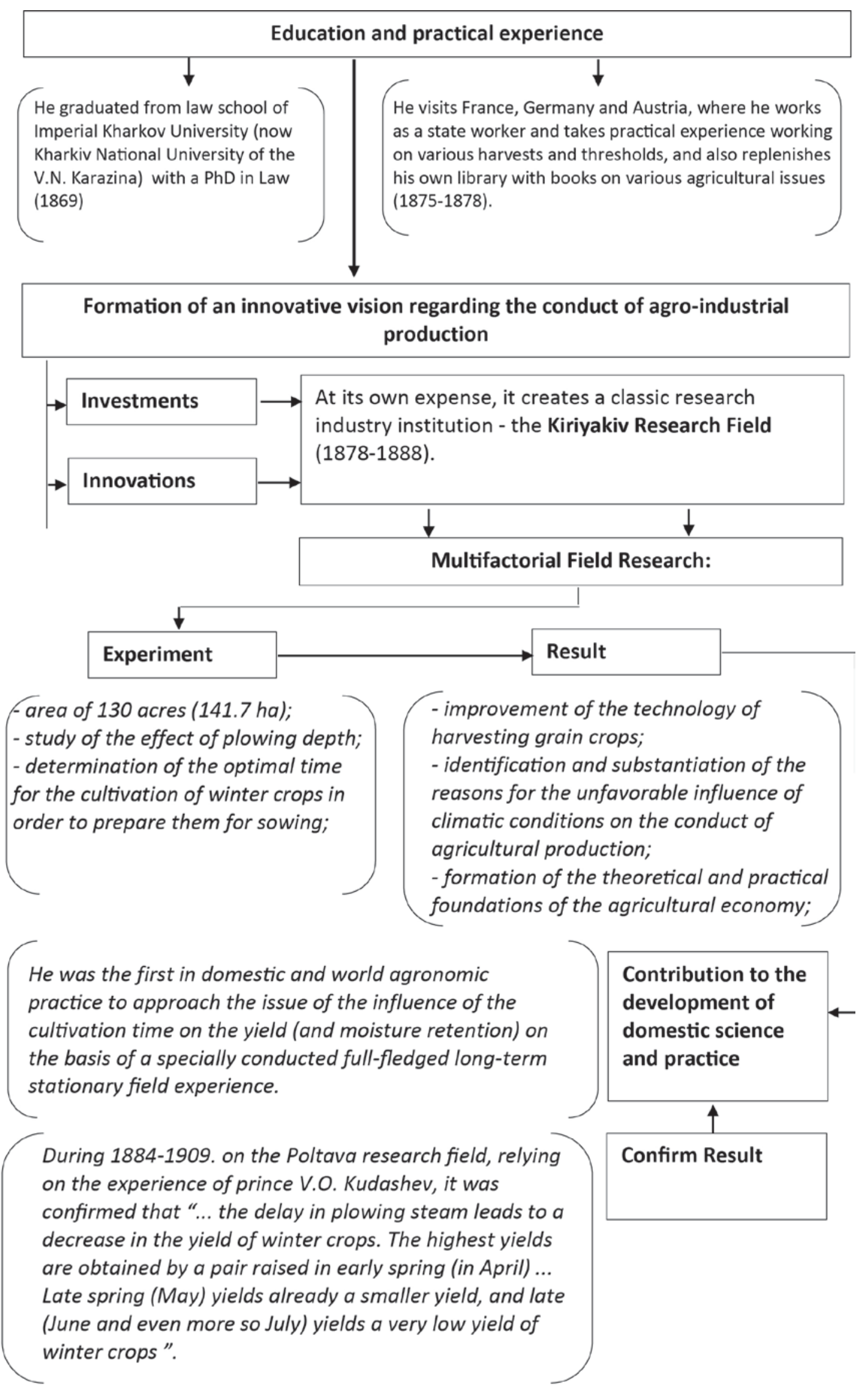

Figure 3. Implementation of an innovative approach to agricultural commodity production, which was proposed by prince $\mathrm{V}$. $\mathrm{O}$. Kudashev

Source: Formed on the basis of research [5, 16]. 
The prince was the first in domestic branch science to change the existing views on the depth of soil cultivation for winter crops and experimentally brought the advantages of shallow soil cultivation as an effective approach to preserving soil moisture, improved the technology of harvesting grain crops, especially winter crops, formed the theoretical and practical foundations for such a science, as an agrarian economy, primarily in matters of the cost of agricultural products [22].

It should also be noted that the advantages of the approach proposed by V.O.Kudashev became fully apparent in 1891, when all winter crops of the Poltava research field died (in that part of it where the innovations proposed by the prince were not used), and in the prince the harvest reached 119 poods per tithe, and the seedlings of winter crops appeared already on September 23, 1892 [23].

For innovative approaches to agricultural production, prince V.O. Kudashev was awarded the gold medal of the Imperial Free Economic Society in 1896, and in 1892 the large silver medal of the Imperial Moscow Society of Agriculture [22].

The scientific works of the prince for 1889-1910 consists of 212 publications, of which - 7 books and brochures, 118 articles, 17 reviews and 69 "answers" to the questions of readers of the weekly "Agricultural newspaper". In many respects, it is thanks to such conscientious figures of the highest aristocracy as Prince $\mathrm{V}$. O. Kudashev that the formation of agricultural research as a field of knowledge, as well as a part of natural science [24-25].

The prince handed over all the results obtained to the Poltava Research Field, created in 1884 - the first stateowned permanent agricultural research institution in the country. The principles of soil moisture conservation developed by prince V.O. Kudashev remain the basis for modern organic farming and domestic plant growing, and are widely used in practice [22].

\section{Conclusions}

So, the investment and innovation content of the business environment is a complex dynamic system, the purpose of which is to promote the sustainable development of the agricultural sector by providing the opportunity to attract, distribute and invest monetary, material and intellectual resources from different sources of origin, taking into account the combined influence of macro- and microenvironment factors to achieve the set goals of own development of any business entity.

The proposed historical example of Prince V.O. Kudashev is an effective example of the implementation of innovative activities and the implementation of the achieved scientific developments in their own production. The developed algorithm for introducing innovations into its own production is still relevant today, since it is based on a scientific and practical approach and allows one to determine the practical value and economic efficiency from the introduction of any innovations into its own production by any business entity.

\section{References}

1. Antoniuk, L.L., Poruchnyk, A.M., \& Savchuk, V.S. (2003). Innovatsii: teoriia, mekhanizm rozrobky ta komertsializatsii [Innovations: theory, mechanism of development and commercialization]. Kyiv: KNEU. [In Ukrainian].

2. Melnyk, O.H. (2011). Formuvannia metodolohichnykh pidkhodiv u doslidzhenniakh innovatsii ta innovatsiinoho rozvytku [Formation of methodological approaches in research of innovations and innovative development]. Current economic problems, 6 (120), 18 - 25. [In Ukrainian].

3. Sabluk, P.T., Shpykuliak, O.H., \& Kurylo, L.I. (2010). Innovatsiina diialnist $v$ ahrarnii sferi: instytutsionalnyi aspect [Innovative activity in the agrarian sphere: institutional aspect: monograph]. Kyiv: NNTsIAE. [In Ukrainian].

4. Sirenko, N.M. (2012). Kontseptualni zasady innovatsiinoho rozvytku ahrarnoho sektoru ekonomiky Ukrainy. [Conceptual bases of innovative development of agrarian sector of economy of Ukraine]. Marketing and innovation management, 1, 234-240. [In Ukrainian].

5. Fedorenko, V.F., Buklagin, D.S., \& Aronov, E.L. Innovatsionnaya deyatelnost v APK: sostoyanie, problemy, perspektivy [Innovative activity in the agro-industrial complex: state, problems, prospects]. Moskva: FRGNU «Rocsinformagrotekh», 2010. [In Russian].

6. Fedulova, L.I. Innovatsiina ekonomika [Innovative economy]. Kyiv: Lybid, 2006. [In Ukrainian].

7. Ivanochko, S.S., \& Svintsov, O.M. (2011). Sut ta vydy investytsii [The essence and types of investments]. Scientific Bulletin of NLTU of Ukraine, 21(15), 181 - 187. [In Ukrainian].

8. Leus, M.M. (2009). Teoretyko-metodolohichni osnovy klasyfikatsii investytsii [Theoretical and methodological bases of investment classification]. Scientific Bulletin of NLTU of Ukraine, 19(1), $130-137$. [In Ukrainian].

9. Pavlov, K.V. (2009). Investitsii i innovatsii intensivnogo i ekstensivnogo tipa: makroekonomicheskiy podkhod [Investment and innovation of intensive and extensive type: a macroeconomic approach]. Theory and practice of social development, 1, $189-197$. [In Russian].

10. Peresada, A.A. (2002). Upravlinnia investytsiinym protsesom [Investment process management]. Kyiv: Libra. [In Ukrainian].

11. Malik, M.I., Kropyvko, M.F., Bulavka, O.H. at al. (2010). Sotsialno-ekonomichni zasady rozvytku silskykh terytorii (ekonomika, pidpryiemnytstvo i menedzhment) [Socio-economic principles of rural development (economy, entrepreneurship and management)]. Kyiv: NNTs IAE. [In Ukrainian].

12. Shevchuk, O.M., \& Rohozzhyn, N.lu. (1999). Osnovy investytsiinoi diialnosti [Fundamentals of investment activity]. Kyiv: Geneza. [In Ukrainian]. 
13. Shumpeter, Y. (1992). Teoriya ekonomicheskogo razvitiya [Theory of economic development]. Moskva: Progress. [In Russian].

14. Denison, E. (1985). Trends in American economic growth, 1929 - 1982. Washington: Bookings institution.

15. Jaffe, A., Lerner, J., \& Stern, S. (2005). Innovation Policy and the Economy. Cambridge, Massachusetts: The MIT Press.

16. Giarratana, M. at al. (2005). The Role of MNCs in the Evolution of the Software Industry in India, Ireland and Israel. Oxford, UK: Oxford University Press.

17. Sakhal, D. (1985). Tekhnicheskiy progress: kontseptsii modeli, otsenki [Technological progress: model concepts, assessments]. from English. Moscow: Finansy i statistika. [In Russian].

18. Tviss, B. (Puzynya K.F. (Ed.)). (1989). Upravlenie nauchno-tekhnicheskimi novovvedeniyami [Management of scientific and technical innovations]. from English. Moskva: Ekonomika. [In Russian].

19. Foster, R. (Danilova-Danilyana V.I. (Ed.)) (1987). Obnovlenie proizvodstva: atakuyushchie vyigryvayut [Production Upgrade: Attackers Win]. from English. Moskva: Progress. [In Russian].

20. Shubravska, O. (2012). Innovatsiinyi rozvytok ahrarnoho sektora ekonomiky Ukrainy: teoretykometodolohichnyi aspect [Innovative development of the agricultural sector of the economy of Ukraine: theoretical and methodological aspect]. Ukraine economy, 1, 27 - 35. [In Ukrainian].

21. Blank, I.A. (2001). Osnovy investitsionnogo menedzhmenta [Fundamentals of Investment Management]. Kiev: Elga-N, Nika-tsentr. [In Russian].

22. Verhunov, V.A. (comp.) (2018). Kudashev Volodymyr Oleksandrovych (1846 - 1916): biobibliohr. pokazhch. nauk. pr. za 1889 - 1903 rr. [Kudashev Vladimir Alexandrovich (1846 - 1916): biobibliogr. show Science. for 1889 - 1903; structure]. Kyiv, NAAN, NNSHB. [In Ukrainian].

23. Tretyakov, S.F., \& Verbetskiy K.L. (1910). Glavneyshie vyvody Poltavskogo opytnogo polya (1884 - 1909 gg.) [The main conclusions of the Poltava experimental field]. Poltava, («Khutoryanin», Vol. I). [In Russian].

24. Iz selskokhozyaystvennoy literatury (1892). [From agricultural literature]. Agricultural newspaper, 32. [In Russian].

25. Modestov, A.P. (1924). Ocherki po istorii agronomii v zhizneopisaniyakh [Essays on the history of agronomy in biographies]. Moscow, 1, 120. [In Russian]. 